\title{
CHANGES IN THE SECONDARY LANDSCAPE STRUCTURE IN HRUBY JESENIK MOUNTAINS (CZECH REPUBLIC)
}

\author{
ADAM DOSTAL $^{1}$, IVO MACHAR $^{2}$, PETER MACKOVCIN $^{3}$ \\ ${ }^{1,2,3}$ Palacky University, Faculty of Science, Tr. 17 listopadu 47, 77146 Olomouc, \\ Czech Republic \\ *Corresponding author e-mail: ivo.machar@upol.cz
}

Received: $9^{\text {th }}$ October 2020, Accepted: $31^{\text {th }}$ October 2020

\begin{abstract}
This study deals with the analysis of changes in the secondary landscape structure of the territory of the Jeseniky Mountains (Czech Republic) monitored in the years 1946, 1953, 1962 , 2000, and 2016. The study analysed georeferencing aerial geodetic images in the QGIS 2.18 program. On the basis of the land use classification key that was created, historical changes were identified in the following categories of land use; forest, arable land, orchards, water surfaces, wild life refuges and scattered greenery, river networks, permanent grass stands, meadows and pastures, gardens and built-up areas, courtyards and hard surfaces. The surface areas of land use categories were utilized for the calculation of change indicators regarding the structure of the landscape (landscape similarity index, coefficient of ecological stability, and change index). The maps for land use created for individual historical periods functioned as the starting point for a comprehensive assessment of the landscape by means of a SWOT analysis, which created the basis for a proposal for permanently sustainable utilization of the landscape in the area that was monitored. The study results indicate that the analysis of the historical development of the secondary landscape structure may be utilized as a decision support tool when planning sustainable landscape management.
\end{abstract}

Key words: GIS, Jeseniky Mountains, landscape history, landscape structure, land-use.

\section{INTRODUCTION}

The cultural landscape originated as an interaction between natural and man-made interventions in the landscape of varying degrees of intensity. Unlike a natural and unaffected landscape, where ecosystem climax periods prevail, in the cultural landscape a mixed mosaic of areas in various stages of disturbances, created by varying degrees of intensity of human activity, can be found (Sklenicka et al., 2017). The spatial landscape structure observes the mutual position of building elements in a landscape unit and it is further divided into the vertical spatial structure (given by geomorphology and elevation segmentation) and the horizontal spatial structure, which determines the territorial distribution of units within a larger unit (Demek et al.,, 2007). On the basis of the character of the relationship between man and the landscape, we can, according to study (Mackovcin et al., 2011), distinguish primary, secondary, and tertiary landscape structures. The primary landscape structure involves all the features of the landscapes that occurred independently of man and which are not under man's direct control. The secondary (functional) landscape structure is a set of 
landscape items created by man and is limited by the ability of man to change his environment. It forms a mosaic of forms of areas that are utilized with varying quality and various designations and it is, in the cultural landscape, the most pronounced part of the landscape structure (Simon et al., 2014). The secondary landscape structure is most obvious from the point of view of anthropogenic perception of the character of the landscape and its change has an impact on the energy and material flows of the primary landscape structure (Lieskovski et al., 2018). The tertiary man-made landscape structure is created by tangible artefacts associated with the spiritual orientation of the society in the period of their origin and with various social parameters over the territory. Here, interests, legislative measures, and traditions meet together and form the tangible thoughts of the current society and of the generation of our ancestors, which are the fundamental attributes of a European cultural landscape (Simon et al., 2015).

The assessment of the long-term use of the landscape has a significant meaning for understanding current and historical links and relationships in the landscape. This is also valid in large-area protected territories, where it is possible to evaluate the impact on the ecosystems and the subject of the protection, as well as the development of land use in a wider sense (Oprsal et al., 2018). One of the fundamental assumptions for evaluating long-term land use is studying old topographic maps. Medium-scale maps allow a basic overview of methods of land use in larger historical units to be acquired (Haase et al. 2007). Changes in land use do not lead only to mere spatial changes in the ratio of individual categories of the landscape surface but they also influence the generic composition and diversity of individual segments (biotopes) which retain their spatial and chronological continuity and those which occur newly and are constantly affected by the surrounding environment (Rehounkova \& Prach, 2010).

This study focuses on analysing historical changes in the secondary landscape structure in the mountainous region of the Hruby Jesenik (Czech Republic). The objective of this study is to highlight the meaning of analysing the historical development of the secondary landscape structure as a decision support tool in planning sustainable landscape management.

\section{METHODS AND MATERIALS}

\section{Study area}

The study area is located in the northern part of the Olomouc region, on the territory of the Sumperk district, and covers an area of approximately 9444.21 hectares. The study area consists of five cadastral areas (Fig. 1). Its geographical position is $50^{\circ} 4^{\prime}$ latitude north and $17^{\circ} 5^{\prime}$ longitude east. The study area is extremely segmented and the difference in altitudes in the area that was monitored is hundreds of metres. The highest peak in the area is Velky Ded, $1408 \mathrm{~m}$ above sea level, and the lowest altitudes are in the southern part of the area, ranging around $400 \mathrm{~m}$ above sea level. 
Fig. 1: Localization of the study area in the Czech Republic and local cadastral areas (Data source: original of authors)

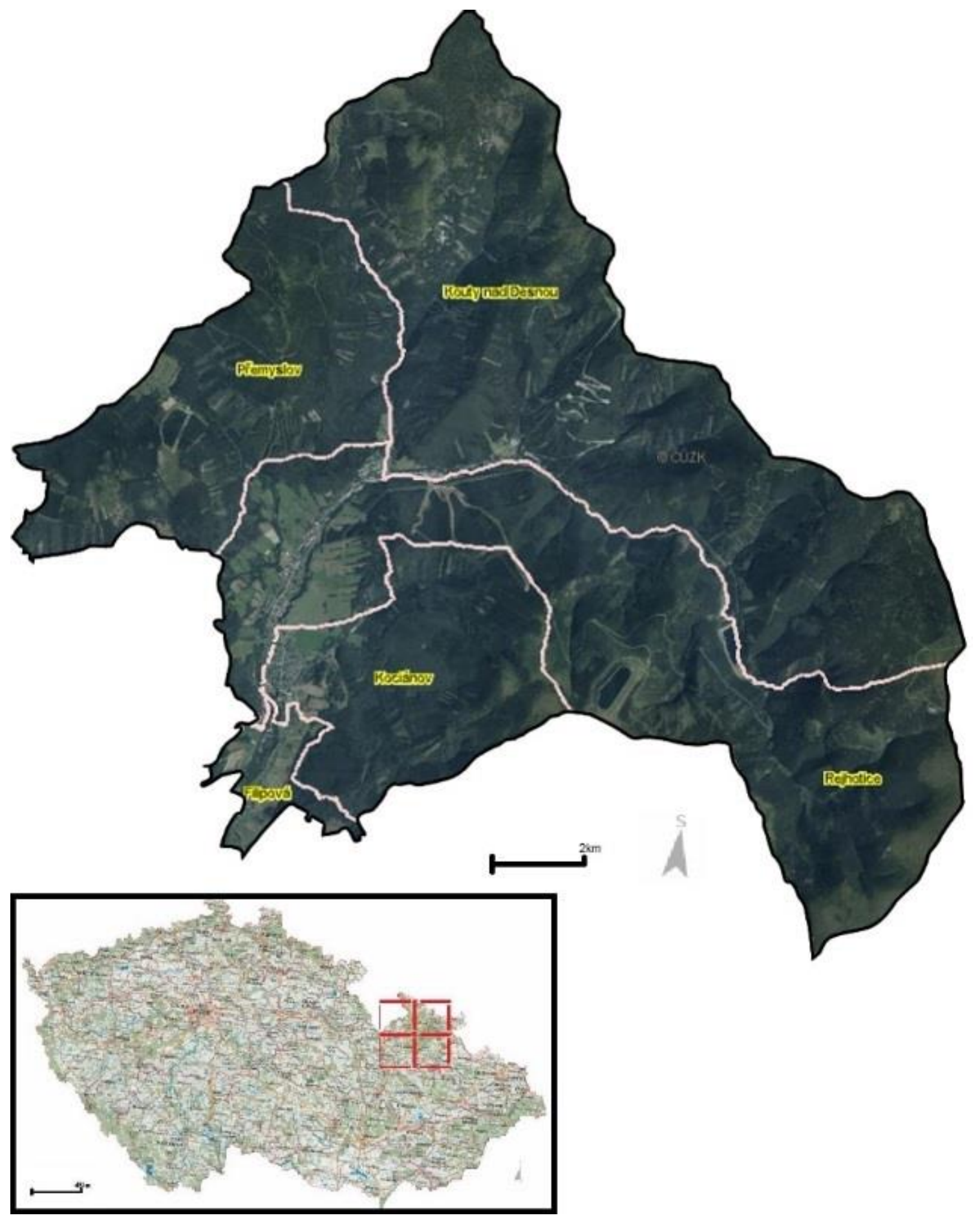


Dostal A., Machar I., Mackovcin P.: Changes in the secondary landscape structure in Hruby Jesenik Mountains (Czech Republic)

The relief of the study area is highly segmented, with high mountain peaks with steep slopes covered with continuous forests overhanging the deeply cut valleys of the Huciva and Divoka Desna brooks.

The entire study area is criss-crossed by a dense network of brooks and streams. It is drained by the River Desna, which belongs to the river basin of the Morava. On the border of the study area stretching along the main ridge of the Hruby Jesenik there is also the main European watershed divide. The region is often hit by flooding and extreme conditions of the streams, the main reason being the absorption potency of the earth in the highest parts of the mountains, where water flows quickly down to the valleys.

The local climate is significantly influenced by the relief (sunny slopes, relative altitude segmentation, and inversion) and vegetation cover. On the mountain ridge, there is a tough wet and windy climate, which becomes more stable and less harsh towards the valleys. The average annual temperature on the highest mountain, Praded, is around $0.9^{\circ} \mathrm{C}$ and the total rainfall is approximately $1300 \mathrm{~mm}$ per year.

In the valley of the Divoka Desna, and to a slightly lesser extent in the valley of the Huciva Desna, floral beech woods with a rich herb layer have been preserved. In the area Cervenohorske sedlo, one can find acidophilic mountainous beech woods frequently represented by sycamores (Acer pseudoplatanus). The vegetation along the water streams can be classified as waterside floodplain forests. The biota is generally diverse, with rare glacial relicts. The main types of trees within the area that was monitored include the common beech (Fagus sylvatica) and common spruce (Picea abies). An example of an unoriginal species is the mountain pine (Pinus mugo) on the upper tree line. In this area, the following animals can be found: wolf (Canis lupus), black grouse (Tetrao tetrix), western capercaillie (Tetrao urogallus), alpine newt (Ichthyosaura alpestris), and mountain ringlet (Erebia piphron).

The oldest residential part of Loucna nad Desnou is Rejhotice (Reitenhau), which was first mentioned as early as in the $14^{\text {th }}$ century in connection with the activities of woodcutters and charcoal burners. The settlement of Premyslov (Primiswald) was only founded in the middle of the $17^{\text {th }}$ century after the forest along the road was cut down. The settlement of Kouty nad Desnou (Winkelsdorf) was established in 1718 and a little later, in 1773, today's Filipova (Phillippsthal) was founded. In 1784, the last settlement (Kozianau) was founded. Something that is essential for the area that was monitored, from the point of view of demography, is the expulsion of a large part of its German inhabitants in the autumn of 1945 and the spring of 1946, when efforts were exerted to populate the area again. However, because of the tough weather conditions, these attempts were not very successful. The fundamental economic activities of the area include tourist services, both in the winter and summer. At present, the study area belongs to the Protected Landscape Area of the Jeseniky Mountains (Machar et al., 2018).

\section{Data collection and analyses}

We used a historical method monitoring the succession of phenomena on the basis of which it might be possible to determine probable future development (Machar et al., 2017). Another method that was applied was the cartographic one, which enables the detection of the shapes and location of elements in the landscape by means of map groundwork. A diagnosis of the secondary landscape structure results in proposals for changes in the functional utilization of the landscape based on natural conditions or in what has been termed the optimal spatial organization of the landscape (Table 1). 
Table 1: Partial steps of the landscape assessment process in study area

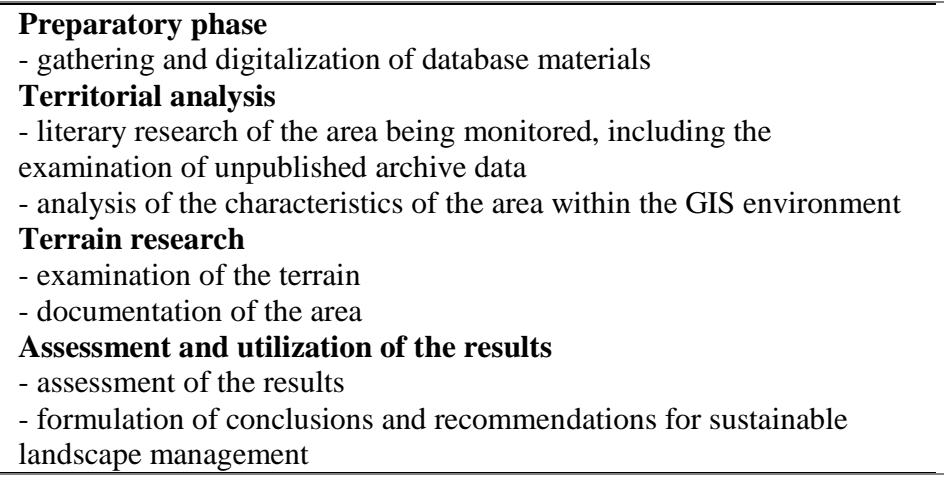

A classification key was created that was relevant to a mountainous landscape, in order to identify the areal representation of individual landscape units (Table 2).

\section{Table 2: Classification key of land use for the study area}

\section{Land use type \\ Road network}

Forest

Arable land

Orchard

Water areas

Wild life refuges and isolated greenery

\section{River network}

Permanent grass stands (PGS), meadow and pasture

Garden

Built-in area, courtyard and hard surface
Characteristics of a land use type

Hard linear areas constructed for transport provided by motor and rail vehicles and hard linear surfaces used for transferring people outside roads.

A piece of land continuously covered with wood species, forest ways with an unpaved surface, or areas serving for renewal of the forest cover. Agriculturally cultivated soil with consecutive growing of agricultural crops and plants.

A piece of land continuously covered with fruit trees or bushes, usually in the vicinity of residential and farm buildings.

Water area, excluding the river network. This includes, especially, a water reservoir, swamp, moss, or morass. This area is bordered with a bank line which is the end point of the normal water level. Areas covered with trees or bushes which do not form a forest and often border arable land or meadows and pastures. This category also includes strips of a field left fallow, wildlife refuges, and solitary trees/bushes.

Area of a watercourse.

Area with dominant species of grasses which is not a garden or orchard where different utilization is not possible.

A piece of land designated for the permanent growing of vegetables, flowers, and other garden crop-plants.

A piece of land containing a residential or farming building, swimming pool, small-size construction, hard driveway, hard courtyard, ruins or demolished constructions, or other hard surface covering the soil, such as outside storage of raw materials, areas under construction, etc. 
Dostal A., Machar I., Mackovcin P.: Changes in the secondary landscape structure in Hruby Jesenik Mountains (Czech Republic)

The QGIS software, version 2.18 Las Palmas, was used for analysing the aerial survey photo and Microsoft EXCEL 2007 for the statistical operations. Subsequently, all the aerial survey photos were georeferenced within the S-JTSK coordinate system and stored in the TIF format. Vectorization based on a classification key (Table 3) was carried out first for 2016 and then retrospectively, according to the method of reverse interpretation (Havlicek et al., 2018), in which the data layers from 2016 were recorded into the previous period of time and changes in the temporal area of the polygons were analysed in comparison with the current conditions of the landscape. After the creation of data layers for all periods of time, the areas of all polygons were quantified and exported to the Microsoft EXCEL 2007 program, in which the statistical calculations and analyses were conducted.

Coefficient of ecological stability (ESC) determines the ratio between relatively stable and relatively unstable areas, according to study (Low \& Michal, 2003):

$$
\text { ESC }=\frac{\text { forest }+ \text { PGS, meadow and pasture }+ \text { gardens }+ \text { orchards }+}{\text { built }- \text { in areas }+ \text { courtyard and hard surfaces }+ \text { arable land }+ \text { road network }},
$$

where ESC can be categorized according to the value of:

a) an ESC up to 0.3 indicates excessive utilization of the area, with a clear infringement of natural structures;

b) the range of ESC $0.4-0.8$ indicates a cultural landscape with a significant application of (agro-) industrial elements being intensely employed;

c) the range of ESC 0.9-2.9 signifies a common cultural landscape where man-made features are in relative harmony with the character of the relatively natural elements;

d) places with an ESC value ranging from 2.9 up to 6.2 represent a landscape with a prevalence of natural elements;

e) where ESC reaches above 6.2, there occur exclusively areas with a relatively natural landscape.

Landscape similarity index (LSIM) (McGarigal \& Marks, 1995) was calculated in line with the equation:

$$
\operatorname{LSIM}=\mathrm{P}_{\mathrm{i}}=\frac{\sum_{\mathrm{j}=1}^{\mathrm{n}} \mathrm{a}_{\mathrm{ij}}}{\mathrm{A}} * 100
$$

where: $a_{i j}=$ area of the category in the given year,

$\mathrm{A}=$ total area of the territory in the same year

The result, shown as a percentage, may reach the values $0<\mathrm{P}_{\mathrm{i}}<100 \mathrm{~m}$ where the resulting values approaching 0 predicate the scarcity of the type of the given item, whereas values reaching 100 indicate that the landscape is predominantly formed by one type of land category. 
Change Index (IZ) according to study (Bicik, 2010) indicates the entire intensity of the development of land use:

$$
I Z_{A-B}=100 * \frac{\sum_{i=1}^{n}\left|R_{i B}-R_{i A}\right|}{2 R c},
$$

where $\mathrm{IZ}_{\mathrm{A}-\mathrm{B}}$ is the change index in the given period and $\mathrm{A}$ to $\mathrm{B}, \mathrm{n}$ is the number of categories, $R_{i A}$ is the area of a category at the beginning of the period and $R_{i B}$ is the area at the end, and $\mathrm{R}_{\mathrm{C}}$ then expresses the entire area of the region being monitored (multiplied by two for the reason of counting the area at the beginning and at the end of the period). The value acquired is $0<\mathrm{IZ}_{\mathrm{A}-\mathrm{B}}<100$, where a higher index means more intense development of the area as it indicates what percentage of the area that was monitored was affected by the change.

\section{RESULTS}

The results from the GIS analyses $\mathrm{d}$ are shown in Table 3, which provides information on the area and landscape similarity index for individual categories of utilization of the study area. The percentage change in the macrostructure of the landscape (Figure 2) reflects the developmental tendency of changes in the utilization of the study area since 1946.

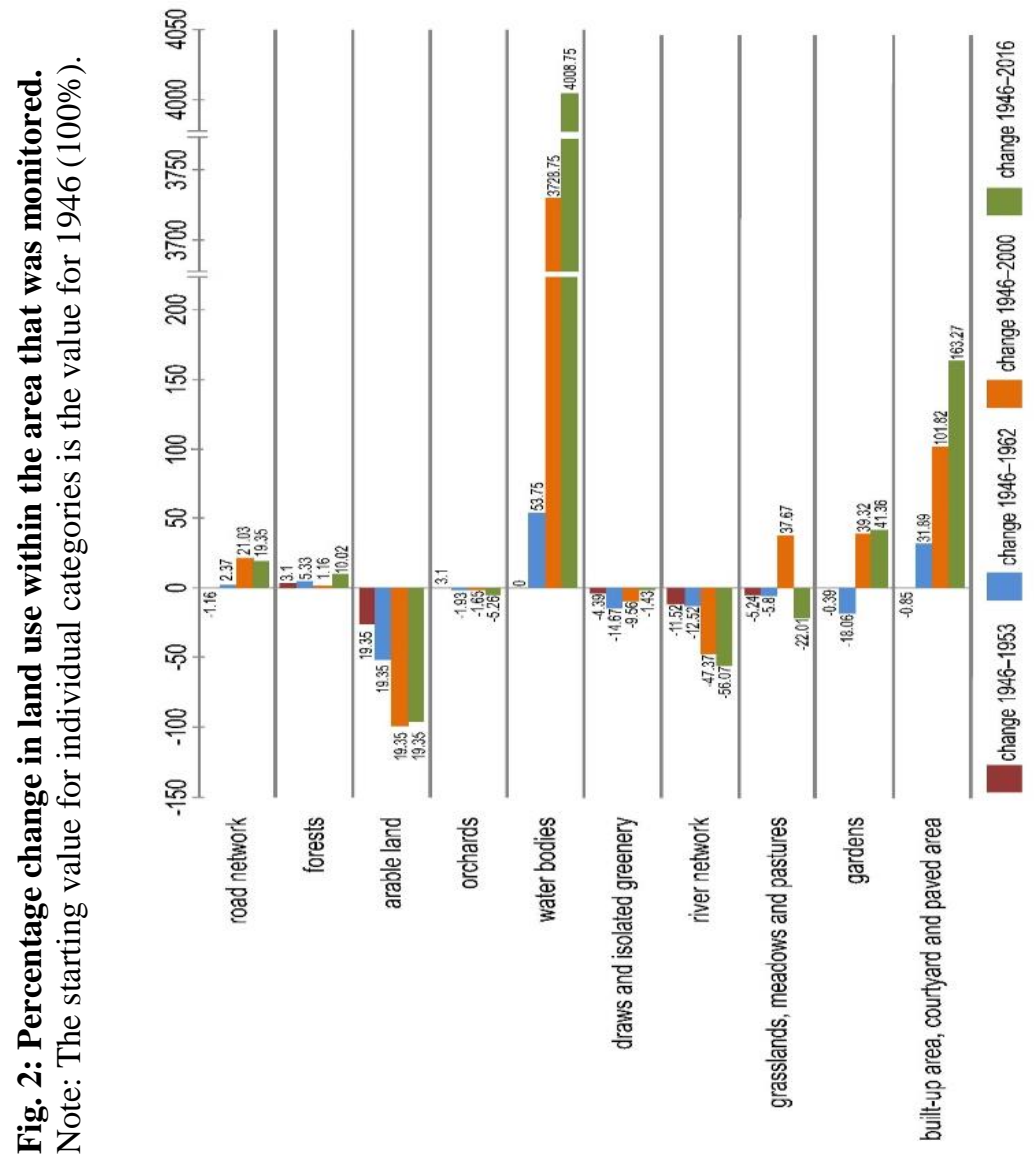




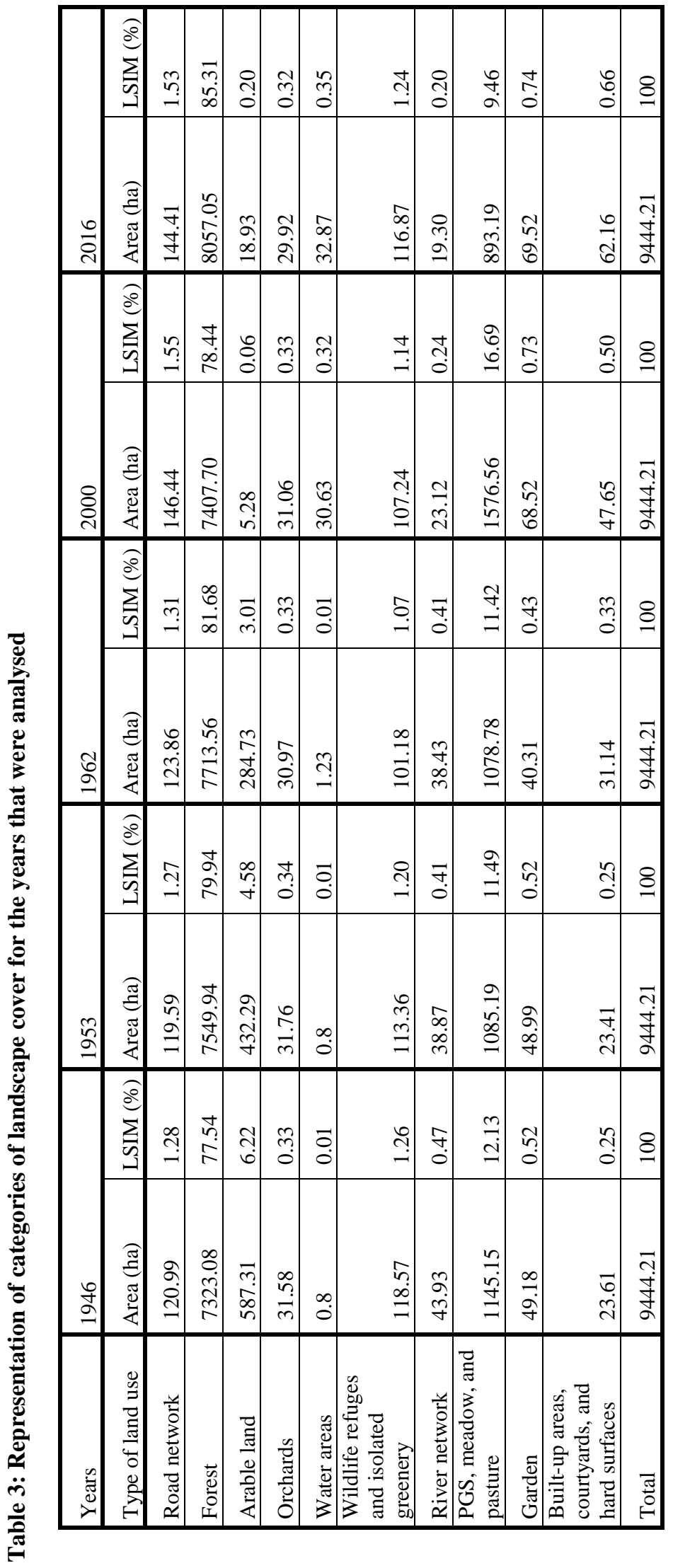


On the study area and within the period of time between 1946 and 2016 that was monitored, the biggest expansion was recorded in the category of forests, 1039.83 ha. To be specific, this goes to show that the landscape tends towards afforestation. The intensity of the afforestation of the area that was monitored is average, with a value of $61.38 \%$ with respect to the entire increment of all the categories that were evaluated.

The coefficient of ecological stability (Table 4) indicates a high ecological stability of the landscape. Since 1946, the ecological stability of the landscape was growing within the region that was monitored up till 2000.

Table 4: Coefficient of ecological stability (ESC) of the region that was monitored

\begin{tabular}{llllll}
\hline Year & $\mathbf{1 9 4 6}$ & $\mathbf{1 9 5 3}$ & $\mathbf{1 9 6 2}$ & $\mathbf{2 0 0 0}$ & $\mathbf{2 0 1 6}$ \\
\hline ESC & 11.9 & 15.42 & 20.48 & 46.37 & 40.88 \\
\hline
\end{tabular}

According to the change index and the temporal sequence, the most intense change happened in the period between 2000 and 2016 (Table 5), when great changes were recorded in the area of forests; PGS, meadows, and pastures. At the same time, the time period between 1962 and 2000 shows the second highest percentage change and is, at the same time, the longest time period according to the temporal sequence. Otherwise, percentage changes are often higher for longer time a period, which is proved by $\mathrm{IZ}_{1946-2016}$, which is the longest time period and which also has the highest value, $8.98 \%$.

Table 5: Change index for the region that was monitored in individual periods of time

\begin{tabular}{llllll}
\hline & 1946 & 1953 & 1962 & 2000 & 2016 \\
\hline 1946 & 0 & 2.4 & 4.25 & 6.51 & 8.98 \\
1953 & 2.4 & 0 & 1.86 & 6.27 & 6.64 \\
1962 & 4.25 & 1.86 & 0 & 6.36 & 4.99 \\
2000 & 6.51 & 6.27 & 6.36 & 0 & 7.31 \\
2016 & 8.98 & 6.64 & 4.99 & 7.31 & 0 \\
\hline
\end{tabular}

The SWOT analysis (Table 6) presented below evaluates, in a comprehensive manner, the condition of the landscape and focuses on sorting out individual points with the aim of supporting the sustainability of the development of the landscape. 
Dostal A., Machar I., Mackovcin P.: Changes in the secondary landscape structure in Hruby Jesenik Mountains (Czech Republic)

Table 6: SWOT analysis prepared for the region that was monitored

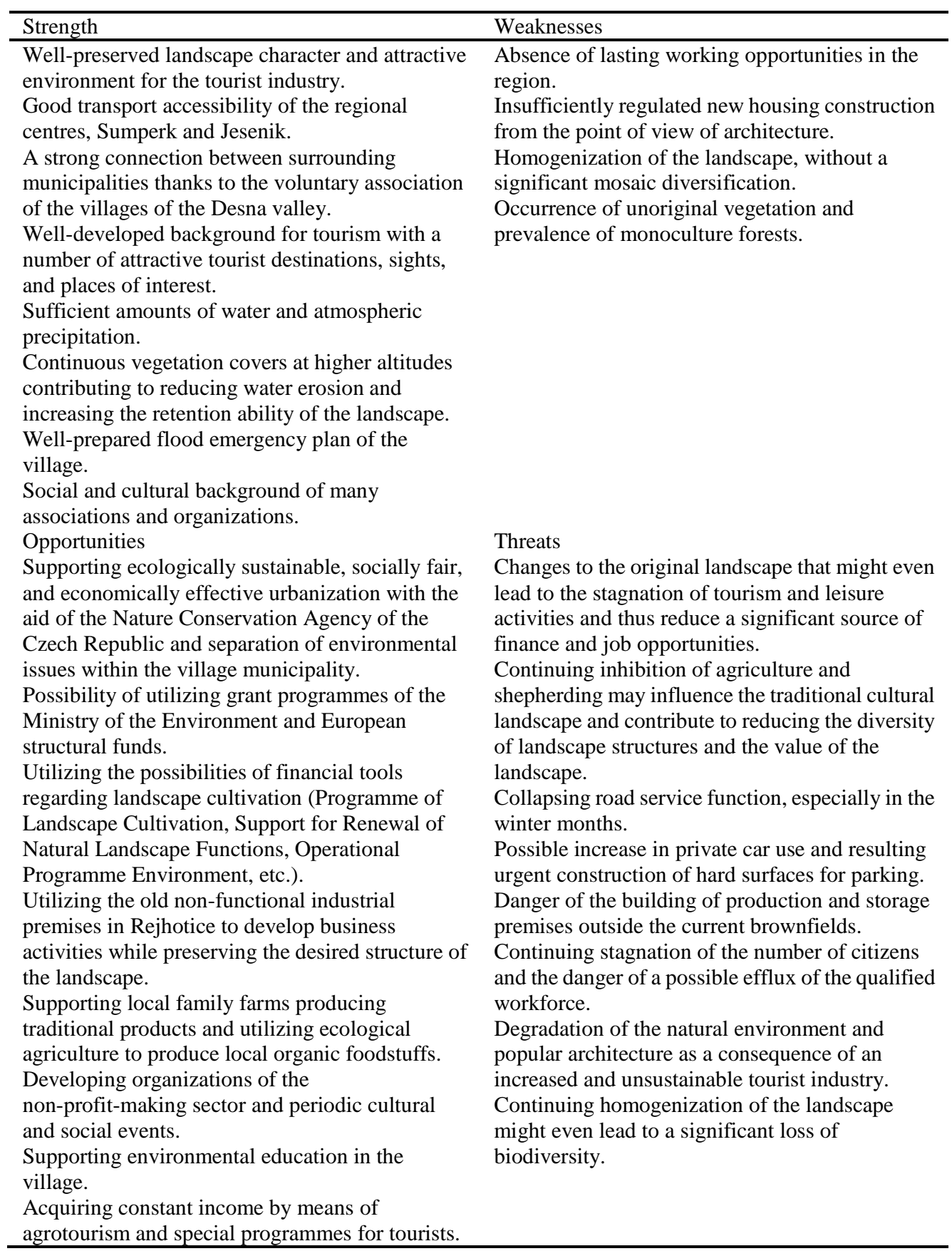




\section{DISCUSSION}

The fundamental presupposition for sustainable landscape development should be abiding by certain landscape utilization patterns in accordance with conditions of sustainability relating to the potential of a particular way of utilizing the landscape, as mentioned by study of Khachatryan et al. (2019). This is, consequently, supplemented by the study Bicik et al. (2015) when talking about a need to respect natural conditions and ecological patterns and simultaneously the necessity of superordinating those aspects above imminent and changeable economic interests. The landscape's memory, which is considered as a conservative force which curbs unsustainable development (Badach \& Raszeja, 2019), should be applied as a skeleton for the stabilization of the landscape. Authors of the study Skalos \& Kasparova (2012) see the sustainability of the vitality of the landscape in establishing harmony between human activities and the essence of the landscape. Further on, they can see a threat to the sustainable development of the landscape in the gradual estrangement of man from the landscape. Results of the study Havlicek et al. (2012) revealed the threat to the sustainability of the utilization of the landscape lies, above all, in the form and shape of residential housing areas, the construction of relaxation parks, unsuitable appropriation of land, and fragmentation of the landscape. According to Pechanec et al. (2018), the water regime of the landscape is absolutely essential and land use should be associated with maximum closing of the hydrological cycle and the cycle of other substances.

The landscape in the study area has already been reshaped by human activities for many centuries, although, as a result of the segmentation of the local landscape, these activities are limited and this region can be classified as a mainly afforested landscape in which the percentage of forest area does not drop below $77 \%$ of the study area. On the grounds of a comparison of a historical change in the development tendency of the secondary landscape structure, we can notice many signs in common with the general development of mountainous and submontane areas throughout the Czech landscape (Krovakova et al., 2015).

The compliance of the development of the LSIM is comparable in forest areas which show, even on the scale of the entire republic, an increasing share during the entire period of study which reached a share of $33 \%$ in the Czech Republic in 1990. This is 2.3 times less than the share of forests in the study area. Compliance in development is also shown in the category of arable land, which shows, in both examples, a decreasing trend. Between 1948 and 1990 arable land on the territory of the Czech Republic recorded a decline from $50 \%$ to $41 \%$, and in the following period, from 1990 to 2000 , a decline from $41 \%$ to $39 \%$, with a constant downward trend. In 2007, arable land represented $38.5 \%$, and this trend was especially obvious in border mountain ranges. In the study area, the value dropped to the value of $0.06 \%$ for 2000. This trend can be explained, first, by the expulsion of Czech German inhabitants from the borderland and, second, by the later cessation of supporting agricultural production and supplementing it with a policy of non-productive functions of agriculture. Other categories compared are orchards and gardens, which, however, belong, according to Romportl et al. (2013), to permanent cultures, together with vineyards and hop fields, which do not occur in the region that was monitored. Nevertheless, as orchards and gardens formed $88.7 \%$ of the area of permanent cultures in the period between 1948 and 1990, we can use the above-mentioned category for a comparison of the development of the region being monitored. The region is, in the period under evaluation, rather characterized by a moderate decline in the shares of these two categories. However, the entire area of the Czech Republic shows an increasing percentage of permanent cultures from $1.9 \%$ to $3 \%$, with a moderate increase between 1990 and 2000. As far as PGS, meadows, and pastures are concerned, they show decreasing values all over the Czech territory. Their share was reduced from $13 \%$ to 
Dostal A., Machar I., Mackovcin P.: Changes in the secondary landscape structure in Hruby Jesenik Mountains (Czech Republic)

$10.5 \%$ over the period from 1948 to 1990 . In this period, even their representation in the region that was monitored recorded a moderate decrease. The following period till 2000 brought about a moderate increase in both monitoring cases. This signifies that the relevant percentage for the Czech Republic is diverging from the one for the analysed region (Opdam \& Steingrover, 2018). Areas of water on the territory of the Czech Republic have been showing a percentage increase since the middle of the $20^{\text {th }}$ century, but this was preceded by a decline in the period between 1845 and 1948 when, above all, ponds were phased out in favour of arable land and the entire area covered by water was reduced from $1.4 \%$ to $1 \%$. Since 1962, the area that was monitored has recorded an enormous percentage increase in this respect but it has only brought about an increase in the share up to $0.32 \%$ in 2000 , which is approximately $2 \%$ less than the current share of areas covered by water in the entire Czech Republic. The built-up area in the region that was monitored shows, at first, a statistically insignificant decline in 1953. Since that year, as is common for the entire Czech Republic, this type of land has recorded a continual increase, but the difference is in the percentage distribution, with the built-up area in the region that was monitored not exceeding $0.66 \%$ and this category within the Czech Republic not dropping below $1 \%$ in the entire country.

If we focus on the years which are the nearest to the years selected in our study, we find out that the average ESC was 0.88 for $1948,1.09$ for 1960 , and 1.18 for 2000. These values indicate that, according to this classification, the Czech Republic had a common cultural landscape. For the area of Loucna nad Desnou, the ESC value was above-average for the entire period and this proves that this is a region which increases the ecological stability of the Czech Republic, especially thanks to the area of forest and the remarkable reduction of the area of arable land during the period of the evaluation of the coefficient. If we assess the data from 2016 for the Olomouc region, the average ESC was 1.01 and the area of the Sumperk showed a value of 3.69, which indicates that a landscape in which civilizing interventions are significant is beginning to prevail in the Sumperk area. We may only claim that in all of the areas that were monitored; the ESC has a growing tendency of varying intensity.

In the region of Hruby Jesenik, changes in alpine timber line were estimated in details in many papers (e.g. Šenfeldr \& Maděra, 2011; Šenfeldr et al., 2014; Roštínský et al. 2013), but this issue is out of aim of this study.

The change index calculated for the period of time between 1845 and 1948, 1948 and 1990, and 1990 and 2000 reached values of $4.8 \%, 11.4 \%$, and $1.9 \%$ within the territory of today's Czech Republic. If we compare the period between 1948 and 1990 with the period between 1946 and 2000, we detect that the changes in the area were lower by $4.89 \%$ in the region that was analysed and thus the landscape did not go through such major changes (in all categories) as the remaining parts of the Czech Republic. The change index, however, is not able to capture changes in locations in the area within each category (Mann et al., 2018).

\section{CONCLUSION}

With reference to the results of the study, the landscape under examination is, at present, afforested on more than $85 \%$ of its area and thus it is highly ecologically stable. On the other hand, insufficient segmentation of the landscape, which means a scant variety of habitats for living organisms, brings about lower biodiversity. That is why it is necessary to select well-balanced management to preserve ecological stability and increase biodiversity. During the period concerned, the region that was monitored shows a tendency to average afforestation, identified by means of the vectorization of LMS images, and also inhibition of 
agricultural activity, proved by a reduction in the areas of the following land types: arable land, PGS, and meadows and pastures.

In the area that was monitored, it is necessary to protect the uniqueness of the landscape, which boasts wooded foothills and picturesque deeply-cut valleys with scattered built-up areas along water streams. With regard to their aesthetic values, meadows and pastures in the vicinity of settlements should be preserved, thus forming a park-forest-steppe landscape. Another essential character is the dense forest cover, which gives the landscape life-giving properties and, at the same time, acts as an awe-inspiring element. The landscape that was monitored is unique and, on the scale of the Czech Republic, it serves as a popular recreational and close-to-nature reserve for many people seeking relaxation in contrast to the ever-accelerating pace of life.

The biggest challenge for the region is to maintain the unique character of its landscape and positive aesthetic values, which might be endangered by the reduction of local farming activities in the landscape, especially shepherding, and also another danger to the landscape as a consequence of increasing numbers of visitors and their demands for comfort and accommodation facilities for their stay and travelling within the region.

\section{ACKNOWLEDGEMENT}

This study was supported by the grant: Forgotten history of mountain forests in Hruby Jeseniky Mts - a key to cultural identity of Moravia and Silesia regions, funded by the Ministry of Culture of the Czech Republic from NAKI II (Programme to Support Applied Research and Experimental Development of National and Cultural Identity).

\section{REFERENCES}

Badach, J., Raszeja, E. (2019). Developing a Framework for the Implementation of Landscape and Greenspace Indicators in Sustainable Urban Planning. Waterfront Landscape Management: Case Studies in Gdansk, Poznan and Bristol. Sustainability 11, article number 2291. Doi: 10.3390/su11082291.

Bicik, I. (2010). Changes in land use in Czechia. Ceska geograficka spolecnost, Prague, 1-250. ISBN 978-80-904521-3-8.

Bicik, I., Kupkova, L., Jelenecek, L., Kabrda, J., Stych, P., Janousek, Z., Winklerova, J. (2015). Land Use Changes in Czechia 1845-2010. Socio-Economic Driving Force. Springer, Heidelberg, 1-229.

Demek, J., Havlicek, M., Mackovcin, P., Slavik, P. (2007). Landscape changes in the Czech Republic 1763-2005 based on historical maps and GIS technology. In: Thematic Mapping in Geosciences, Aplications using New Technologies and Media. (M. Kaasch, J. Kaasch, eds.) Deutsche Akademie der Naturforscher Leopoldina Halle, 187-200. ISBN - 13: 978-3-8047-2407-5

Haase, D., Walz, U., Neubert, M., Rosenberg, M. (2007). Changes to Central European landscapes - Analysing historical maps to approach current environmental issues, examples form Saxony, Central Germany. Land Use Policy 24, 248-263.

Havlicek, M., Krejcikova, B., Chrudina, Z., Svoboda, J. (2012). Long-term land use development and changes in streams of the Kyjovka, Svratka and Velicka river basins (Czech Republic). Moravian Geographical Reports 20, 28-42. 
Dostal A., Machar I., Mackovcin P.: Changes in the secondary landscape structure in Hruby Jesenik Mountains (Czech Republic)

Havlicek, M., Skokanova, H., Dostal, I., Vymazalova, M., Pavelkova, R., Petrovic, F. (2018). The consequences of establishing military training areas for land use development-A case study of Libava, Czech Republic. Land Use Policy 73, 84-94. Doi: 10.1016/j.landusepol.2018.01.039.

Khachatryan, H., Suh, D. H., Xu, W., Useche, P., Dukes, M.D. (2019). Towards sustainable water management: Preferences and willingness to pay for smart landscape irrigation technologies. Land Use Policy 85, 33-41. Doi: 10.1016/j.landusepol.2019.03.014.

Krovakova, K., Semeradova, S., Mudrochova, M., Skalos, J. (2015). Landscape functions and their change - a review on methodological approaches. Ecological Engineering 75, 378-383. Doi: 10.1016/j.ecoleng.2014.12.011.

Lieskovsky, J., Kaim, D., Balazs, P., Boltiziar, M., Chmiel, M., Grabska, E., Kiraly, G., Konkoly-Gyuro, E., Kozak, J., Antalova, K., Kuchma, T., Mackovcin, P., Mojses, M., Munteanu, C., Ostafin, K., Ostapowicz, K., Shandra, O., Stych, P., Radeloff, V.C. (2018). Historical dataset of the Carpatians region (1819-1980). Journal of Maps 14, 644-651.

Low, J., Michal, I. (2003). Krajinny raz. Lesnická práce, Kostelec nad Cernymi Lesy, 1- 552. ISBN 80-86386-27-9.

Mackovcin, P., Borovec, R., Demek, J., Eremiasova, R., Havlicek, M., Chrudina, Z., Ryskova, R., Skokanova, H., Slavik, P., Svoboda, J., Stranska, T. (2011). Land use Changes in the Czech Republic. The Silva Tarouca Research Institute for Landscape and Ornamental Gardening, Pruhonice, 1-68. ISBN 978-80-85116-91-5.

Machar, I.; Vozenilek, V.; Simon, J.; Pechanec, V.; Brus, J.; Fulnecek, P.; Vitek, T. (2017). Joining of the historical research and future prediction as a support tool for the assessment of management strategy for European beech-dominated forests in protected areas. Nature Conservation-Bulgaria, 22, 51-78. Doi: 10.3897/natureconservation.22.12902.

Machar, I., Vlčková, V., Šálek, L., Pechanec, V., Nowak, A., Nowak, S., Plášek, V., Švajda, J., Opršal, Z., Topacoglu, O. (2018). Environmental Modelling of Forest Vegetation Zones as a Support Tool for Sustainable Management of Central European Spruce Forests. Journal of Landscape Ecology 11, 3: 45-63.

Mann, C., Garcia-Martin, M., Raymond, C.M., Shaw, B., Plieninger, T. (2018). The potential for integrated landscape management to fulfil Europe's commitments to the Sustainable Development Goals. Landscape and Urban Planning 177, 75-82. Doi: 10.1016/j.landurbplan.2018.04.017.

McGarigal, K., Marks, B. J. (1995). Fragstats: Spatial pattern analysis program for quantifying landscape structure. Department of Agriculture Forest Service, Portland,1-99.

Opdam, P., Steingrover, E. (2018). How Could Companies Engage in sustainable Landscape Management? An Exploratory Perspective. Sustainability 10, article number 220. Doi: 10.3390/su10010220.

Oprsal, Z., Harmacek, J., Pavlik, P., Machar, I. (2018). What Factors can Influence the Expansion of Protected Areas around the World in the Context of International Environmental and Development Goals? Problemy Ekorozwoju 13, 145-157.

Pechanec, V., Machar, I., Pohanka, T., Oprsal, Z., Petrovic, F., Svajda, J., Salek, L., Chobot, K. (2018). Effectiveness of Natura 2000 system for habitat types protection: A case study from the Czech Republic. Nature Conservation-Bulgaria 24, 21-41. Doi: 10.3897/natureconservation.24.21608. 
Rehounkova, K., Prach, K. (2010). Life-history traits and habitat preferences of colonizing plant species in longterm spontaneous succession in abandoned gravel-sand pits. Basic and Applied Ecology 11, 45-53.

Romportl, D., Chuman, T., Lipsky, Z. (2013). Landscape typology of Czechia. Geografie 118, 16-39.

Roštínský, P., Šenfeldr, M., Maděra, P. (2013). Effects of dwarf pine stands on slope deformation processes, as a basis for their management in the Hrubý Jeseník Mts. Journal of Landscape Ecology 6 (1): 63-83.

Simon, J., Machar, I., Bucek, A. (2014). Linking the historical research with the growth simulation model of hardwood floodplain forests. Polish Journal of Ecology 62, 273-288. Doi: 10.3161/104.062.0208.

Simon, J., Machar, I., Brus, J., Pechanec, V. (2015). Combining a growth-simulation model with acoustic-wood tomography as a decision-support tool for adaptive management and conservation of forest ecosystems. Ecological Informatics 30, 309-312. Doi: 10.1016/j.ecoinf.2015.08.004.

Skalos, J., Kasparova, I. (2012). Landscape memory and landscape change in relation to mining. Ecological Engineering 43, 60-69. Doi: 10.1016/j.ecoleng.2011.07.001.

Sklenicka, P., Kottova, B., Salek, M. (2017). Success in preserving historic rural landscapes under various policy measures: Incentives, restrictions or planning? Environmental Science \& Policy 75, 1-9. Doi: 10.1016/j.envsci.2017.05.010.

Šenfeldr, M., Maděra, P. (2011). Population Structure and Reproductive Strategy of Norway Spruce (Picea abies L. Karst) Above the Former Pastoral Timberline in the Hrubý Jeseník Mountains, Czech Republic. Mountain Research and Development 2011: 1-13. Doi: 10.1659/MRD-JOURNAL-D-10-00073.1.

Šenfeldr, M., Treml, V., Maděra, P., Volařík, D. (2014). Effects of prostrate dwarf pine on Norway spruce clonal groups in the treeline ecotone of the Hrubý Jeseník Mountains, Czech Republic. Arctic Antarctic and Alpine Research 46 (2): 430-440. Doi: 10.1657/1938-4246-46.2.430. 